\title{
Agama Pra-Islam Perspektif Al-Qur'an
}

\author{
Dewi Anggraeni \\ Universitas Negeri Jakarta \\ gadisghumi06@gmail.com
}

\begin{abstract}
This paper discusses how the Qur'an speaks of pre-Islamic religions which originally came from a monotheistic religion whose brought by Abraham. Explicitly the Qur'an gives the message essentially the same message between the Qur'an and the earlier books. This message give a signals the continuity of God's message in which all the semitic religions revealed in the Qur'an lead to the prophet Abraham. So the semitic religions have the same mission to purify Tauhid as a peace religion based on submission to God. At once refine again the belief of those who believe in supernatural powers that are limited to the beliefs of myth. Finally the coming of the prophet Muhammad was to support, confirm, rectify, and perfecting the teachings of the former religion.
\end{abstract}

Keywords : Religions, Pre-Islamic, Monotheistic.

\begin{abstract}
Abstrak
Tulisan ini membahas tentang bagaimana al Quran membicarakan agama-agama praIslam yang awalnya berasal dari satu agama monoteisme yang di bawa oleh Ibrahim. Secara eskplisit al-Qur'an memberikan pesan secara esensial adanya pesan yang sama antara al-Qur'an dengan kitab-kitab sebelumnya. Pesan ini memberikan isyarat adanya keseinambungan risalah Tuhan dimana semua agama semitik yang diungkap dalam al-Qur'an bermuara kepada nabi Ibrahim As. Sehingga agama-agama semitik memiliki misi yang sama untuk memurnikan Tauhid sebagai agama kedamaian yang berlandaskan kepasrahan kepada Tuhan. Sekaligus memurnikan kembali kepercayaan orang-orang yang meyakini kekuatan adikodrati yang hanya sebatas keyakinan dari mitos. Akhirnya kedatangan nabi Muhammad adalah untuk mendukung, mengukuhkan, meluruskan kembali, dan menyempurnakan ajaranajaran agama terdahulu.
\end{abstract}

Kata Kunci : Agama, Pra-Islam,Monoteisme.

\section{A. Pendahuluan}

Dalam konteks hitoris kepercayaan terhadap hal yang ghaib adalah hal yang paling hakiki karena menyangkut hubungan yang sangat esensial antara manusia dengan sesuatu yang adikodrati, ghaib dan transenden. Pengalaman ghaib dan keterbatasan manusia yang kemudian mendorongnya untuk menemukan adanya kekuatan yang mengatasi kekuatannya sendiri. Mengutip perkataan Rudolf Otto gejala yang melampaui daya tanggkap manusia itu sendiri disebut misteri, yaitu sesuatu yang tidak pernah dimengerti tetapi tidak dapat disangkal keberadaannya dalam pengalaman manusia. Pengalaman transenden tersebut 
yang kemudian mendorong manusia akan keberadaaan Tuhan yang dikenali lewat sebuah agama.

Agama yang dianut oleh berbagai juataan umat dipelbagai belahan bumi tidak datang secara sekaligus, akan tetapi melalui berbagai tahapan yang panjang. Agama hadir mengikuti tingkat perkembangan intelektual serta kondisi manusia. Sehingga, agama selalu cocok untuk manusia di sepanjang waktu. Proses dan perkembangan agama dapat ditelusuri melalui sejarah agama itu sendiri seperti halnya Nabi Adam, sebagaimana yang diabadikan dalam Al Quran, memeluk konsep agama yang sangat sederhana dan tidak banyak pengaruh peran syariat.

Syariat yang dianut dan diyakini tidaklah lepas dari kehadirannya para nabi dan rasul yang membawa syariat itu sendiri. Sebagaimana ajaran nabi Muhammad Saw yang membawa risalah terakhir dalam rumpunan agama semetik berbekal dengan al Quran sebagai pedoman. Al Quran hadir tidak sebatas sebagai petunjuk bagi orang-orang yang bertakwa akan tetapi lebih dari itu sebagai petunujuk bagi umat manusia. Dengan kata lain al Quran mengakui adanya agama serta kitab suci umat-umat sebelumnya. Sebagaimana firman Allah Swt dalam surat al shaffat bahwa Allah Swt mengutus Muhammad Saw, salah satu dari tugasnya adalah membenarkan para rasul sebelumnya. Bahkan pengakuan Islam atas agama-agama sebelumnya diabadikan dalam landasan teologis beragama yakni rukun iman. Umat islam diwajibakan untuk mengimanai para rasul sebelum nabi Muhammad Saw dan kitab-kitab selain dari al Quran.

Secara eskplisit al Quran memberikan pesan secara esensial adanya pesan yang sama antara al Quran dengan kitab-kitab sebelumnya. Pesan ini memberikan isyarat adanya keseinambungan risalah Tuhan dimana semua agama semitik yang diungkap dalam al Quran bermuara kepada nabi Ibrahim As. Sehingga agama-agama semitik memiliki misi yang sama untuk memurnikan Tauhid sebagai agama kedamaian yang berlandaskan kepasrahan kepada Tuhan. Sekaligus memurnikan kembali kepercayaan orang-orang yang meyakini kekuatan adikodrati yang hanya sebatas keyakinan dari mitos. Akhirnya kedatangan nabi Muhammad adalah untuk mendukung, mengukuhkan, meluruskan kembali, dan menyempurnakan ajaran-ajaran agama terdahulu.

Lantas bagaimana al Quran mengisahkan agama-agama pra-Islam, dimana pada awalnya dibawa oleh bapak agama yang satu yaitu Ibrahim As yang selanjutnya dalam al Quran di abdikan dengan istilah Millah Ibrahim Hanifa, hingga kemudian memunculkan agama-agama dengan berbagai sebutannya. Selanjutnya bagaimana konteks al Quran menceritakan historis keyakinan manusia secara spiritualitas dan religiusitas serta 
perubahan yang terjadi sehingga Muhammad Saw membawa Risalah terakhir untuk umat manusia serta bagaimana al Quran melihat agama-agama pra-Islam. Bagaimana transforamsi millah Ibrahim menjadi din Islam sebagai risalah universal yang menyempurnakan agama-agama sebelumnya.

\section{B. Istilah Agama Dalam Al Quran}

Al Quran membicarakan perkembangan keyakinan-keyakinan dan agama-agama masyarakat Arab yang hidup pada masa pra dan era kenabian Muhammad Saw. Al Quran menyebutkan istilah keyakinan dengan berbagai kata. Dalam hal ini Darwah salah satunya sengaja menggunakan istilah 'aqidah' (keyakinan) dan din (agama) keduanya dilihat terkadang saling berhubungan dan terkadang terjadi perbedaan. Dimana keyakinan lebih khusus dari pada agama. Keyakinan atau aqidah adalah kepercayaan terhadap keberadaan sesuatu. Sedangkan agama atau al din merupakan ajaran yang meliputi keyakinan, tradisitradisi atas pemikiran keagamaan ${ }^{1}$. Istilah lain yang ada dalam al Quran diantaranya:

\section{a. Millah}

Dari perspektif bahasa, secara etimologi, kata millah berasal dari Bahasa Aram. Aram adalah salah satu suku yang ada di jazirah Arabia ${ }^{2}$. Menurut Az-Zamakhsyari, kata millah berarti tata cara yang dilalui. Ar-Raghib al-Ashfahani (w.502 H) mengatakan, millah - seperti juga dengan dîn - adalah sebutan bagi apa yang telah disyariatkan oleh Allah kepada ummat manusia melalui para nabi-Nya agar manusia dapat berhubungan dengan-Nya. Pengertian senada disebutkan oleh Ibrahim al-Mu'jam al'Wasith". Dalam bahasa Turki diistilahkan dengan "millet", istilah yang digunakan oleh Turki Utsmani untuk seluruh agama yang berkembang di wilayahnya. Bahkan dalam bahasa Turki dan Persia, kata "millet" sering dipakai dalam pengertian "bangsa, rakyat, atau negara"

Dalam pemakaiannya, kata millah umumnya disandarkan pada Nabi yang membawanya, seperti millah Abraham (Ibrahim), millah para Nabi (Syu'aib, Ismail, dan keturunan Ishaq as.). Kata yang sering digunakan Al Quran untuk memaknai millah adalah kata dîn, yang berasal dari kata "dana-yadînu-dînan; bila ia menyertai, menyerah kepada, dan menaati seseorang)". Beberapa ulama seperti Abu al-A'la al-Mawdudi

\footnotetext{
${ }^{1}$. Aksin Wijaya, Sejarah Kenabian; Perspektif Tafsir-Nuzuli Darwah, Kairo: Dar Ihya al Kutub Al Arabiyah, hal : 255 .

2. M. Yudie R. Haryono, Bahasa Politik Alquran: Mencurigai Makna Tersembunyi di Balik Teks, Bekasi: Gugus Press, 2002, hal: 244

3. Ibrahim Anis, Al-Mu'jam al-Waisth, Kairo, Jilid 2, hal. 887.

4 . Cyrill Glasse, Ensiklopedi Islam (Ringkas), Jakarta: Raja Grafindo, 1999, hal.269.
} 
mendefenisiskan millah dengan din yang memiliki karakteristik sama, dimana kata dîn itu memiliki tiga arti; pertama, kehormatan pemerintah, negara dan kekuasaan; kedua, ketundukan, kepatuhan, penghambaan dan penyerahan diri; arti ketiga, memperhitungkan, mengadili, memberi hukuman atas perbuatan-perbuatan ${ }^{5}$.

Kata millah sendiri tercatat dalam lima belas ayat Al Quran dengan berbagai konteks bahasan, yang umumnya berhubungan dengan para Nabi, khusunya Nabi Abraham $(\text { Ibrahim })^{6}$. Beberapa derivasi kata millah dalam al Quran diantaranya surat al Baqoroh ayat 130. Yang artinya "Lalu siapa yang tidak suka akan millah Ibrahim, selain orang yang membodohkan dirinya sendiri ..." munasabah ayat tersebut dengan ayat sebelumnya menjelaskan bahwa ayat tersebut sebagai penutup dari cita-cita dan harapan Ibarahim dalam konteks ini al Quran surat Al Baqoroh ayat 126-129. Teks ayat dengan makna serupa terulang kembali dalam surat Ibrahim ayat 35-41. Teks Lafadz "millah" terdapat pula dalam surat Al Imran ayat 97. At Tabari dalam Jamiul bayan menjelaskan maksud dari kata millah ada hanif yakni lurus dengan makna tauhid ${ }^{7}$. Dengan kata lain tauhidnya Ibrahim yang mengesakan tuhan.

Sementara menurut Ar Razi dalam mafatihul ghaib “millah” Ibrahim adalah serupa dengan millah yang dibawa oleh Muhammad Saw. Yang mengajarkan manusia akan keesaan Tuhan dengan ajaran tauhid, Maksud millah Ibrahim adalah millah yang dibawa nabi Muhammad Saw yang ushulnya sama mengajak manusia untuk mengesakan tuhan dan menyakini kenabian serta memilkiki akhlak yang mulia. Akan tetapi berbeda di dalam furu atau syariatnya dan ibadah. Karena syariat disesuaikan dengan kondisi. Dalam syariat Ibrahim tidak mewajibkan untuk menyakini kenabiaan Muhammad berbeda dengan syariat Islam menyakini akan nubuwah Ibrahim yang tertuang dalam rukun iman percaya kepada para nabi dan rasul. Di samping nubuwah dan kerasulan beberapa ibadah yang disyariatkan kepada Ibrahim telah di manuskh dalam al Quran namun secara ushul samasama membawa pesan tauhid, nubuwah,dan akhlak yang mulia ${ }^{8}$. Sehingga inilah yang membedaakan antara syariat Ibrahim dan Muhammad.

Dapat disimpulkan bahwa menurut ar Razi defenisi millah memiliki dua makna yakni ushul dan furu. Secara Ushul millah bermakna agama yang sama-sama membawa

\footnotetext{
5 . Abu al-A'la al-Mawdudi, Dasar-dasar Islam, penerj. Achsin Mohammad, Bandung: Pustaka, 1997, hal.94

6 . Muhammad Fu'ad 'Abdu al-baqi, Al-Mu'jam al-Mufahras Li Alfazh Alquran Al-Karim, Bairut: Dar al-Fikr, 1981, hal.676

${ }^{7}$. At Thabari, Jamiul Bayan Fi Tafsir Al Quran, Tafsir surat al Baqoroh 130 ayat diakses melalui maktabah tafsir digital.

${ }^{8}$.Ar Razi, Mafatihul Ghaib, Tafsir surat al Baqoroh 130 ayat diakses melalui maktabah tafsir digital.
} 
pesan sama meng-Esa-kan Tuhan. Sementara secara furu defenisi millah bermakna syariat. Dalam kontkes syariat tidak semua yang menjadi syariat Ibrahim berlaku pula dalam syariat Muhammad.

Kata millah dalam al Quran tidak disandarkan kepada Allah (millah Allah) berbeda dengan kata din. Dîn disandarkan menjadi dîn Allah karean melihat Allah sebagai Pemilik dan sumber dari dîn tersebut. Karena itu Allah sebagai ad-Dayyan (sumber dan Yang memerintahkan hukum). Bila kata dîn disandarkan kepada pengikutnya, seperti kata dîniy (agamaku) atau dînukum (agama kalian), maka hak itu didasarkan pada ketaatan dan ketundukan dari si penganut. Sehingga tafsiran para mufasir memberikan definisi yang sama antara millah dan din. Meskipun penggunaan kata millah tidak disandarkan kepada Allah, tidak mengurangi ke universalan ajaran Ibrahim dengan Tauhidnya sehingga dijuluki bapaknya para Nabi. Dalam hal ini al Quran menegaksan dalam surat al Baqarah ayat 124 dengan kata imam. "Dan (ingatlah), ketika Ibrahim diuji Tuhannya dengan beberapa kalimat (perintah dan larangan), lalu Ibrahim menunaikanya. Allah berfirman: "Sesungguhnya Aku akan menjadikanmu imam bagi seluruh manusia".

Kata Imam dari ayat di atas pun berarti bahwa Ibrahim membawa millah dan misi yang bersifat universal; rahmatan li al-alamin. Jika Ibrahim sendiri dijanjikan sebagai pemimpin bagi seluruh manusia, ini berarti kepada anak generasinya pun berlaku hal yang sama. Karenanya, doktrin agama bahwa setiap Nabi diutus hanya untuk bangsanya sendiri (Nabi lokal) adalah sebuah penyimpangan. Demikian pula dengan universalitas Kitab Suci yang dibawanya juga berlaku kepada semua manusia, semua suku bangsa, bukan hanya khusus kepada Bani Israel atau Bani Ismail semata. Allah, misalnya, menegaskan bahwa Kitab Suci Taurat dan Injil adalah Kitab petunjuk bagi semua umat manusia ${ }^{9}$, demikian halnya dengan Al Quran ${ }^{10}$. Jika Kitab Suci sebagai petunjuk para Nabi dan Rasul bersifat universal, berarti para Rasul sebagai penyampai risalah pun bersifat universal karena mereka bertindak atas dasar petunjuk wahyu dalam Kitab Suci itu.

Semua kepemimpinan dan misi para Nabi sejatinya bersifat universal, meskipun pada awal kenabiannya atau masa hidupnya mereka memulai da'wahnya dari bangsanya

9. Al Quran surat Ali 'Imran (3) ayat 3-4 dan surat Al-Maidah (5) ayat 44, 46. Dalam Alkitab Perjanjian Baru juga dikisahkan bagaimana Yesus menyembuhkan seorang perempuan Kanaan yang bukan dari kalangan Israel. Aritnya, Yesus Kristus tidak hanya diutus untuk domba-domba Israel saja.

${ }^{10}$.Al Quran surat al-Baqarah (2) ayat 2: "Kitab (Alquran) ini tidak ada keraguan padanya, petunjuk bagi mereka yang bertaqwa", dan ayat 185: "(Beberapa hari yang ditentukan itu ialah) bulan Ramadhan, bulan yang di dalamnya diturunkan (permulaan) Alquran sebagai petunjuk bagi manusia dan penjelasanpenjelasan mengenai petunjuk itu dan pembeda (antara yang hak dan yang bathil)...” 
masing-masing. Hal ini disebabkan karena setiap bangsa memiliki akar sejarahnya masingmasing, sehingga setiap Nabi dan Rasul memulai misinya dari bangsanya sendiri.

\section{b. Din}

Dalam Kamus Al-Munjid, Ad-Din (Jama: Adyan) diterjemahkan menjadi: (1)AlJaza wa `l-Mukafaah; (2) Al-Qadha; (3) Al-Malik/al-Mulk wa `s-Sulthan; (4) At-Tadbir; (5) Al-Hisab. Menurut Moenawar khalil kata 'din' itu mashdar dari kata kerja 'daana' 'yadienu'. Menurut lughat, kata 'din' itu mempunyai arti bermacam-macam, antara lain berarti: 1) Cara atau adat kebiasaan. 2) Peraturan. 3) Undang-undang. 4) Tha`at atau patuh. 5) Menunggalkan ketuhanan. 6) Pembalasan. 7) Perhitungan. 8) Hari Qiyamat. 9) Nasehat. 10) Agama ${ }^{11}$. Menurut Ibn Manzhur kata 'din' ini secara etimologis digunakan dalam empat makna:

'Din' dalam makna hukum, kuasa, tunduk, mengatur dan perhitungan (al-hukm wa siyasat al-umur wa al-qahr wa al-tadbir wa al-muhasabah) ${ }^{12}$. Sementara kata din dalam makna ketertundukan, taat, pengabdian, tunduk (al-taskhir, wa al-itha'at wal abdiyah wa $\left.a l-k h u d u^{\prime}\right)^{13}$. Disamping itu Ibn Manzhur menjelaskan din memiliki makna pembalasan, perhitungan dan ganjaran (al-jaza' wa al-hisab wa al-mukafa'ah).

Menurut Az Zabidi dalam kamus 'Taj al- 'Arus' dikemukakan bahwa makna 'din' adalah al-jaza' (pembalasan/ganjaran). Din dalam konteks ini erat kaitannya dengan din dalam makna aqidah (al-I'tiqad). Sehingga din berdasarkan pandangan ini adalah jalan atau syariat yang dilaksanakan oleh seseorang ${ }^{14}$. Hal serupa ditegaskan oleh Ibn Faris dalam 'Mu'jam Maqayis al-Lughah' dalam entri 'd-y-n' berpendapat bahwa semua akar kata tersebut berasal dari asal yang sama, dan makna derivasinya juga merujuk kepada makna asalnya. Sehingga 'din' bermakna semua jenis dari ketertundukan dan keterhinaan $(\text { al-inqiyad wa al-dzull })^{15}$.

11. Munawar Khalil, Defenisi dan Sendi Agama, Bulan Bintang, 1970, hal :13.

12 . Contohnya : دانه دينا و دان الناس : قهر هم على الطاعة . Contoh lain, misalnya dikemukakan dalam hadits Nabi saw : الكيس من دان نفسه وعمل لما بعد الموت : Makna 'dana' dalam hadits diatas adalah 'qahara nafsahu' menundukkan hawa nafsunya'. Oleh karena itu Nabi Muhammad saw dipanggil oleh para pujangga Arab : Ya Sayyid al-Nas wa Dayyan al-Arab. Lebih lanjut lihat Ibn Manzhur, Lisan al-Arab, Dar al-Ma'arif, Cairo, Mesir

أريد من قريش كلمة : Dalam hadits Nabi saw misalnya dikemukakan . دان له : أطاعه وخضع له : Contohnya . ـ Makna 'tudiinu biha' disini adalah taat dan tunduk. Lebih lanjut lihat Ibn Manzhur, Lisan alArab, Dar al-Ma'arif, Cairo, Mesir

14. Begitu juga Al-Zamakhsyari dalam kitab 'Asas al-Balaghah' memaknainya dengan 'al-jaza'. Dalam hadits Nabi dikemukakan : ان الله ليدين للجماء من ذات القرن . Din dalam hadits ini bermakna 'memberikan balasan atau mengganjar’. Lebih lanjut lihat Abdurrazak Zabadi, Tajul Arus min Jawahir Qomus, Kuwait.

15 . Bila merujuk pada pandangan Ibn Faris, maka semua makna etimologis yang dikemukakan diatas merupakan species dari makna genus "ketertundukan dan keterhinaan". Lebih lanjut lihat M. Fuad Abdul Baqi, al-Mu'jam al-Mufahras lialfazh al-Qur'an al-Karim, Mu'assah al-Jamal, Beirut, Lebanon 
Kata Ad-Din mempunyai arti perhitungan (al-hisab), pembangkitan (al-ba`ts), pembalasan (al-jaza), ketetapan (al-qodho), ganjaran (ats-tsawab), siksaan (al-iqob), ketika al-Quran membicarakan tentang hari qiyamat . sebagaimana terdapat dalam surat alfatihah : 4, al-hijr : 35 , an-nur : 25, asy-syuara : 82 , as-shofat : 20, shod : 78, adz-dzariyat : 6, 12, al-waqiah : 56, al-maarij : 26, al-mudatsir : 46, al-infithor : 9, 15, 17, 18, almuthofifin : 11 , at-tin : 7 al-maun : 1 .

Sementara kata Ad-Din mempunyai makna ibadah, doa, tauhid, ketaatan ketika alQuran membahas tentang pemurnian terhadap Allah. Seperti yang terdapat pada surat albaqoroh : 193, an-nisa : 146, al-a`raf : 29, al-anfal : 39, yunus : 22, yusuf : 40, an-nahl : 52 , al-ankabut : 65, ar-ruum : 30, luqman : 32, az-zumar : 2, 3, 11, 14, ghofir : 14, 65, albayyinah : 5 .

Kata Ad-Din mempunyai arti hukum dan ketetapan ketika al-Quran membahas mengenai pengambilan hukum yang dilakukan olehNya maupun yang dilakukan oleh hambaNya seperti dalam surat yusuf: 76, an-nur: 2. Sedangan Kata Ad-Din berarti sesuatu yang dianut oleh manusia ketika berada dalam konteks pembahasan mengenai keyakinan seperti dalam surat al mumtahanah : 8, 9, al-fath : 28, al-ahzab : 5, ali-imran : 24, an-nisa : 60 al-kafirun : 6.

Banyaknya makna yang terkandung dalam lafadz ad din dilatar belakangi karena Al-Qur'an banyak sekali mengungkapkan kalimat 'din' dalam berbagai surat dan ayat. Kata tersebut terulang dalam 92 kali dan semuanya dalam bentuk tunggal (mufrad), tidak ada satupun dalam bentuk jamak (adyan).

Makna-makna kata din secara etimologi jika dikonversikan kepada penggunaaan ayat-ayat al Quran, maka secara terminologis makna kata din menggandung beberapa makna yakni: Pertama, Kekuasaan tertinggi dan hukum Allah (al-Sulthat al-Ulya wa alHukm Lillah). Kedua adalah ketertundukan dan taat kepada kekuasaan Allah (al-Tha'at wa al-Idz'an lihakimiyat Allah wa Sulthanihi). Kedua makna ini sangat erat kaitannya bahkan dapat ditemui keterkaitan maknanya satu sama lain dalam ayat yang sama. Adapun ayatayatnya dalam al Quran adalah surat al Imran ayat 83, “ Maka apakah mereka mencari agama yang lain dari agama Allah, padahal kepada-Nya-lah berserah diri segala apa yang di langit dan di bumi, baik dengan suka maupun terpaksa dan hanya kepada Allahlah mereka dikembalikan”. 
Menurut Qurtubi makna dari kata din dalam ayat tersebut dipertegas dengan kata aslama yang artinya tunduk dan patuh dan taat ${ }^{16}$. Makna serupa terdapat pada surat al Bayinah ayat 5, an Nahl ayat 52, Ghafur ayat 65. Kata 'din' dalam ayat-ayat di atas bermakna kekuasaan tertinggi dan ketertundukan kepada kekuasaan tertinggi tersebut serta menerima ketaatan dan pengabdian kepada-Nya.

Ketiga, makna dari 'din' adalah syariat dan sistem kehidupan di bawah kekuasaan Tuhan (al-Syariat wa al-Nizham al-Ka'in tahta Sulthan Allah wa Hakimiyyatihi). Kata din dengan makna ini terdapat pada surat Yunus ayat 104-105. Makna 'din' dalam ayat di atas mempunyai makna syariat dan sistem kehidupan (amaliyah) yang dilakukan manusia terhadap ajaran agama. Apabila hukum dan syariat dimana manusia terikat dan tunduk pada aturan yang bersumber dari Tuhan, maka ia berada dalam agama Tuhan. At Tabri memaknai din terkait syariat yang bersumber dari tuhan maka bagi umat Islam terikat dengan syariat tersebut bukan berpaling kepada syariat-syariat sebelumnya seperti Yahudi dan Nasrani ${ }^{17}$.

Sedangkan apabila ia tunduk pada sistem dan aturan buatan manusia, maka ia berada pada sistem bikinan manusia, seperti ditegaskan dalam surat Yusuf ayat 76; "Tidaklah patut Yusuf menghukum saudaranya menurut aturan Raja”. Makna Din dalam ayat ini adalah sistem kekuasaan Raja Mesir pada masa Nabi Yusuf.

Keempat din dimaknai dengan ganjaran dan hitungan (al-Jaza wa al-Mukafa'ah). Al Quran mengemukakan beberapa ayat terkait dengan makna ini diantaranya surat ad Dzariat ayat 5-6, al Infithor ayat 17-19, as Shafat ayat $20^{18}$. Kata 'din' dalam Al-Qur' an juga ada yang idhafat dengan al-haq (din al-haq). Misalnya dalam surat al-Tawbah: 33 dan Al-Shaf: 9 dan juga surat al-Fath :28.

Dari pemaparan diatas terkait makna din maka mayoritas ulama tafsir membedakan antara makna dîn dan millah. Abu Hilal al-Askari, misalnya, berpendapat bahwa dîn adalah sebutan untuk apa yang dianut oleh ummat yang menganutnya, sedangkan millah adalah sebutan bagi kumpulan syariat. Sementara pendapat alAshafahani menyamakan makna keduanya. Kesamaan makna antara dîn dan millah ini dapat dilihat dari fiman Allah dalam Alquran surat al-An'am ayat 161 "Sesungguhnya aku

\footnotetext{
${ }^{16}$. Al Qurtubi, Jami li Ahkam Al Quran, Tafsir surat Al Imron ayat 83, diakses lewat maktabah tafsir digital

17. At Tabari, Jamiul Bayan Fi Tafsir Al Quran, Tafsir Surat Yunus ayat 104-105, diakses diakses lewat maktabah tafsir digital

${ }^{18}$. At Tabari, Jamiul Bayan Fi Tafsir Al Quran, Tafsir Surat as Shafat ayat 20, diakses diakses lewat maktabah tafsir digital
} 
telah ditunjuki oleh Rabb-ku kepada jalan yang lurus, (yaitu) dîn (agama) yang benar, millah (agama) Ibrahim yang lurus; dan Ibrahim itu bukanlah termasuk orang-orang yang musyrik".

Persamaan makna keduanya juga tertera pada surat asy-Syura ayat 13, "Dia telah mensyariatkan bagi kamu (Muhammad) tentang dîn (agama) apa yang telah diwasiatkan-Nya kepada Nuh dan apa yang telah kami wahyukan kepadamu dan apa yang telah kami wasiatkan kepada Ibrahim, Musa, dan Isa”.

Pada ayat pertama, jelas bahwa yang dimaksud oleh Allah dengan istilah shirath almustaqim (konsep kehidupan yang lurus) itu adalah dîn al-qayyim; sistem hukum yang benar, yaitu millah Abraham itu sendiri. Millah Abraham inilah yang kemudian diajarkan pula oleh Allah kepada Nabi Muhammad. Yang pada haekaktnya sama-sama mengajarkan tauhid. Sedangkan pada ayat kedua, ditegaskan kembali bahwa dîn yang diwasiatkan (disyariatkan dan diwahyukan) oleh Allah kepada Nabi Muhammad adalah dîn yang dulu telah disyariatkan-Nya kepada Nabi Nuh, Abraham, Musa, dan Isa putra Maryam. Perintah dasar kepada mereka pun sama, yakni tegakkan dîn (hukum). Hal ini juga berarti bahwa millah merekapun semuanya sama.

\section{c.Syir'ah}

Secara etimologis, syir'ah atau syara' menurut kata dasarnya berarti jalan ke sumber air atau jalan terang yang harus dilalui atau jalan yang harus diikuti oleh orang-orang beriman ${ }^{19}$. Menurut At Thabari semua umat memiliki syir'ah yakni syariat. Kemudian pengertian kata ini dipinjam untuk digunakan pada pengertian istilah bagi setiap jalan yang ditetapkan oleh Allah yang tidak berubah, yang datang kepada kita melalui salah seorang nabi . Pendapat lain menurut Thabatthabi dalam kata syariat diambil dari akar kata "syara'a" yang berarti "air yang banyak" atau "jalan menuju sumber air". Dari pengertian itu kemudian diambil untuk menyebut jalan ketuhanan. Agama adalah sumber kehidupan rohani sebagaimana air yang menjadi sumber kehidupan jasmani ${ }^{20}$.

Secara terminologis Syari'ah dalam banyak pengertian ulama Islam adalah aturanaturan atau hukum-hukum Tuhan yang tertuang dalam al-Qur'an dan sunnah Nabi Muhammad $\mathrm{saw}^{21}$. Aturan-aturan ini meliputi kompleksitas kebutuhan manusia baik yang bersifat individual maupun kolektif. Dengan kata lain syari'ah adalah penumbuhan

19 . Dairah al Ma'arif al Islamiyah, Dar al Fikr, Beirut, vol. III, hal. 242

20. Abdul Ghafur, Millah Ibrahim dalam al-Mizan fi Tafsir al-Qur'an Karya Muhammad Husein athThabathaba'i, (Yogyakarta:Bidang Akademik UIN Sunan Kalijaga, 2008), 170.

21 . sebagaimana Thabari menefenisikan syir'ah dengan syariah. At Tabari, Jamiul Bayan Fi Tafsir Al Quran, Tafsir Surat al Maidah ayat 48, diakses diakses lewat maktabah tafsir digital 
(pelembagaan) kehendak Tuhan dengan mana manusia harus hidup secara pribadi dan bermasyarakat.

Abu Ishak al Syathibi, menyatakan bahwa syariat merupakan aturan-aturan Tuhan dengan mana manusia "mukallaf" (dewasa) mendasarkan tindakan-tindakan, ucapanucapan dan keyakinan-keyakinannya. Inilah kandungan syariat secara global ${ }^{22}$.

Maka syariat dalam pengertian istilah yang berlaku adalah aturan yang diletakkan oleh Allah ta'ala bagi para hamba-Nya berupa hukum-hukum yang dibawa oleh salah seorang nabi di antara para nabi-Nya. Jadi syariat adalah buatan Allah bukan hasil ijtihad manusia; bersifat tetap, tidak berubah. Pendapat serupa dikemukakan oleh Thabthbai bahwa syariat adalah jalan terbentang untuk suatu umat tertentu dan nabi tertentu yang diutus, dan untuk umat tertentu pula,sebagaimana syariat Nuh, syariat Musa, syariat Isa, dan syariat Muhammad ${ }^{23}$.

Dengan demikian, maka syariat mempunyai arti yang spesifik dibanding din yang bersifat umum dan mencakup semua umat. Begitu spesifiknya kata syariat, ia tidak dapat dinisbahkan kecuali kepada orang yang membawa dan menyampaikannya. Penyebutan kata syariat Ibrahim adalah khusus bagi syariat Ibrahim, dan tidak mungkin disebutkan dengan syariat Ibrahim dan Isa. Sebab syariat Ibrahim adalah khusus dan syariat Isa adalah khusus pula.

Dengan demikian mulai terlihat perbedaan antara penggunaan kata millah, din dan syir'ah. Jika millah dan din bermakna universal dengan pesan tahudinya, hanya berbeda penisbatan. Maka syir'ah lebih spesifik terkait pada aturan, hukum dan ketentuan yang mengikat pada umat tertentu. Jika terdapat syariat yang baru yang dibawa oleh para rasul dalam wahyu maka syariat yang barulah yang dipakai. Penghapusan syariat sebelumnya dimansukh (abrogasi) dalam al Quran sebagaimana dalam surat al Baqoroh ayat 106. Legitimasi adanya perbedaan syariat dalam fiqih dikenal dengan syarhu man qablana.

\section{d. Minhaj}

Manhaj dalam bahasa Arab adalah sebuah jalan terang yang ditempuh sebagaimana menurut At Thabari jalan yang terang dan jelas, yakni jalan yang ditempuh dengan terang dan jelas ${ }^{24}$.

22. Al Muwafaqat fi Ushul al Ahkam, Muhammad Ali Subaih, Mesir, hal. 49

23. Abdul Ghafur, Millah Ibrahim dalam al-Mizan fi Tafsir al-Qur'an Karya Muhammad Husein athThabathaba'i, (Yogyakarta:Bidang Akademik UIN Sunan Kalijaga, 2008), 171.

${ }^{24}$. At Tabari, Jamiul Bayan Fi Tafsir Al Quran, Tafsir Surat al Maidah ayat 48, diakses diakses lewat maktabah tafsir digital 
Kata minhaj tedapat pada surat al Maidah ayat 48 "Dan Kami telah turunkan kepadamu al-Qur'an dengan membawa kebenaran, yaitu kitab-kitab (yang diturunkan sebelumnya) dan batu ujian terhadap kitab-kitab yang lain itu; maka putuskanlah perkara mereka menurut apa yang Allah turunkan dan janganlah kamu mengikuti hawa nafsu mereka dengan meninggalkan kebenaran yang telah datang kepadamu, Kami berikan aturan (syir'ah) dan jalan yang terang (minhaj). Sekiranya Allah menghendaki, niscaya kamu dijadikan-Nya satu umat (saja), tetapi Allah hendak menguji kamu terhadap pemberiannya kepadamu, maka berlomba-lombalah berbuat kebajikan. Hanya kepada Allahlah tempat kembali kamu selamanya, lalu diberitahukan-Nya kepadamu apa yang telah kamu perselisihkan itu.". Kata minhaj dalam ayat tersebut menurut Ibnu Abbas, maknanya adalah sunnah. Sedang sunnah artinya jalan yang ditempuh dan sangat terang. Demikian pula Ibnu Katsir menjelaskan hal yang serupa ${ }^{25}$.

Dari beberapa kata yang digunakan dalam pengistilahan agama dalam al quran al Thabathabai memberikan benang merah akan perbedaan kata-kata tersebut, penggunaan kata Syariat dalam al Quran mempunyai arti lebih khusus dari pada al Din.Syariat adalah jalan atau cara-cara yang ditempuh oleh suatu masyarakat/bangsa atau oleh seorang Nabi, seperti syari'at Nabi Nuh, syari'at Nabi Ibrahim, syari'at Nabi Musa, syari'at Nabi Isa dan syari'at Nabi Muhammad saw.

Sementara din adalah jalan ketuhanan (al thariqah al ilahiyah) yang bersifat menyeluruh (universal) untuk semua bangsa. Syariat bisa di naskh (dihapus/diganti), tetapi tidak untuk $\operatorname{din}^{26}$. Beberapa ulama kontemporer seperti Muhammad Syaltut, Sayyid Sabiq dan Thabathabi, membedakan syariat dan aqidah, antara din, millah dan syariat. Aqidah adalah dasar prinsipal agama, sedang syariat adalah cabang, atau jalan menuju agama. Aqidah hanya satu dan sama antara satu Nabi dengan Nabi yang lain. Sedang syariat bisa berbeda-beda dari satu Nabi ke Nabi yang lain karena tergantung waktu dan umat yang berbeda pula.

\section{Agama-Agama Dalam Al Quran}

Dari pembahasan kata din yang pada kemudian diistilahkan dalam bahasa Indonesia dengan agama, dapat disimpulkan bahwa dîn mempunyai dua pengertian yang

25. Hal ini diistilahkan berbeda dalam Tafsir Ibnu katsir kendati memiliki makna yang sama . samamana menunjukan jalan yang terang yang ditempuh. Untuk lebih lanjut lihat Taftsir Ibnu Katsir. Perekembangan kata minhaj selanjutnya dalam Kamus Besar Bahasa Indonesia minhaj adalah pendekatan atau metode.

${ }^{26}$. Al Mizan fi Tafsir al Qur-an, Al A'lami, Beirut, vol. V, hal.358 
digunakan secara umum dan khusus. Dalam arti umum agama bersifat luas yakni sunah, tariqah, dan sabil yang berlaku di masyarakat sehingga semua kepercayaan adalah agama ketika mereka percaya akan ada sesuatu yang lain di luar mereka dalam istilah study agama yang adikodrati di luar batas manusia.

Sedangkan dalam pengertian khusus agama adalah sunah atau tariqah ilahiyah yang berlaku bagi semua umat manusia. Agama dalam arti khusus ini sesuai dengan fitrah manusia yang tujuannya adalah mencapai kebahagian. Agama yang sesuai dengan fitrah semacam ini adalah agama yang benar, yang tidak akan bisa didapat kecuali dengan petunjuk wahyu dan kenabian ${ }^{27}$.

Agama dalam kemutlakannya berfungsi sebagai pegangan dan tuntunan hidup yang memerlukan kadar kepastian yang tinggi dan memberikan kepastian yang tinggi. Atas dasar tersebut sehingga suatu ajaran agama berada dalam daya dan kemampuan manusia untuk melaksanakannya, jika tidak maka agama menjadi absurd ${ }^{28}$.

Sehingga inilah agama-agam semit diutus. Dalam konteks ini al Quran menyebutkan istilah agama sebagai fitrah manusia mahkhluk yang bertuhan dan dengan agama tersebut dapat mengantarkan kepada kebahagiaan. Sehingga konsep agama semit sama-sama mentauhdikan Tuhan. Bermula dari nabi Adam yang mengenalkan manusia kepada sang pencipta. Kisah penciptaan Adam pada dasarnya mempunyai pesan yang jelas. Adam, yang secara harfiah berarti "ketiadaan", di-"wujud"-kan oleh Allah menjadi ada sebagai manusia pertama di muka bumi. Proses ini menyadarkan Adam bahwa ia adalah seorang ciptaan (makhlûq) dan Allah adalah Pencipta (Khâliq). Penciptaan adalah puncak inovasi dan mukjizat, karena manusia tidak akan mampu membuat yang serupa ${ }^{29}$. Al Quran menyebutkan agama-agama yang dianut manusia, hal ini tidak terlepas dari kondisi masyarakat saat itu. Diantara agama- agama tersebut adalah:

\section{a. Yahudi}

Al Quran makkiyah dan al Quran madaniyah banyak membicarakan kaum Yahudi. Sekitar 50 surat dalam al Quran berbicara tentang Yahudi. Konteks al Quran membicarakan tentang Yahudi dalam dua fase pertama prakenabian dan era kenabian ${ }^{30}$. Al

27. Fitrah berasal dari ibda al kalaq yakni kesucian dan agama yang benar. Sebagaimana fitrah manusia adalah bebas dari noda dan dosa. Dalam defenisi ini fitrah bermakna keimanan. Dimana pada hakekatnya semua manusia adalah makhluk yang bertuhan. Sejalan dengan firman allah dalam surat al Araf ayat 172-173. Fitrah juga berati "agama yang benar" sebagaimana firman Allah dalam surat ar Rum ayat 30. Lebih lanjut lihat sadullah afandy, menyoal status agama pra Islam, Bandung, mizan, 2015, hal 169.

28 . Nurkholis Madjid, Islam dan Doktrin Peradaban, Jakarta, Paramadina, hal 329.

29. Muhammad Ali Ash-Shabuni, Kenabian dan Riwayat Para Nabi. Jakarta: PT. Lentera Basritama,200,hal 140.

30. Aksin Wijaya, Sejarah Kenabaian, Bandung: Mizan, 2016, hal 421. 
Quran berbicara tentang kaum yahudi pada masa pra kenabian terkait dengan asal usul dan sikap mereka kepada nabi Musa, Mariyam dan Isa. Hal ini di latar belakangi historis Ibrahim. Ibrahim yang selanjutnya dalam konteks ini disebut Abraham adalah orang Semit yang nama aslinya adalah Abram, diperkirakan lahir sekitar tahun $2166 \mathrm{SM}^{31}$. Hanya saja terdapat perbedaan tentang silsilah geneologis Abraham.

Sejarah asal muasal dari millah Yahudi, Nasrani (Kristen). Dan Islam tentu saja tidak bisa dilepaskan begitu saja dari akar kesejarahan teologi Abraham dan Abraham sendiri sebagai figur sentral. Dalam tradisi Yahudi, Abraham adalah penerima perjanjian (kovenan) asli antara orang-orang Ibrani dengan Allah. Dalam tradisi Nasrani, Abraham adalah patriark terkemuka dan penerima suatu perjanjian formatif yang orisinil dengan Allah yang selanjutnya disarikan sebagai kovenan Mosaik, sedangkan kovenan kedua diyakini telah dibuat untuk Yesus Kristus. Sedangkan dalam tradisi Islam (Arabisme), Ibrahim adalah sosok teladan dari seorang pewarta wahyu yang memiliki akidah yang tak tergoyahkan dan seorang monoteis yang kokoh (Muslim hanif), serta pembawa millah Abraham yang diamanahkan Allah untuk diajarkan kepada keturunannya dan segenap umat manusia.

Di dalam Kitab Kejadian diterangkan, silsilah Abram disebutkan sebagai putera Terah, putra Nahor I, putra Serug, putra Arpakhsad, putra Sem, putra Nuh a.s., putra Lamekh, putra Metusalah, putra Henokh, putra Yared, putra Mahaleel, putra Kenan, putra Enos, putra Set, putra Adam. Sedangkan dalam Al Quran menyebut Abraham sebagai putra $\mathrm{Azar}^{32}$. Dalam al Quran dikisahkan bagaimana Abraham mencari hakikat sebenarnya akan Tuhan dalam komunikasi intra-personal inilah salah satu bukti bahwa Abraham adalah sosok seorang Nabi ${ }^{33}$ Allah yang dipilih untuk menyampaikan risalah-Nya di muka bumi.

31. Secara etimologi, Abram mungkin berasal dari kata Abi'ram yang berarti “terpujilah bapak (saya)". Jerald F. Dirks,Ibrahim Sang Sahabat Tuhan, penerj. Satrio Wahono, Jakarta: Serambi, 2006 , hal. 24. Dia memiliki dua orang saudara, yaitu Nahor dan Haran. Ketika berumur sembilan puluh sembilan tahun, namanya diganti oleh Allah menjadi Abraham. Lihat, Alkitab Perjanjian Lama Kitab Kejadian 17: 1-5

32 . Alquran surat Al-An'am (6) ayat 74,'Dan (ingatlah) diwaktu Ibrahim berkata kepada bapaknya, Azar: "Pantaskah kamu menjadikan berhala-berhala sebagai tuhan-tuhan? Sesungguhnya aku melihat kamu dan kaummu dalam kesesatan yang nyata". Di dalam Alquran, Abraham disebut dengan nama Ibrahim, yang terulang sebanyak 69 kali yang terdapat dalam 24 surat. Muhammad Fu'ad Abdu al-Baqi, Al-Mu'jam alMufahras Li Alfazh Alquran Al-Karim,hal.1-2. Adapun pembahasan lebih lanjut soal geneologi Abraham, lihat Jeral F. Dirks, Ibrahim Sang Sahabat Tuhan, hal. 26-37

33 .Kosakata "prophet (Nabi)" dalam bahasa Inggris dan kata-kata turunannya, seperti "prophecy (kenabian)" dan "prophesize (meNabikan)" berasal dari kosakata bahasa yunani "prophetes". Istilah ini merupakan terjemahan kata dalam bahasa Ibrani (dan Arab) "Nabi", yang berasal dari bahasa Akadia, yang berarti "to call(menyerukan)"; to announce (mengumumkan), dan to speak for (menyampaikan". Maka seorang Nabi adalah seseorang yang mengumumkan atau menyampaikan suatu 
Dengan keteguhan dan kekuatan imannya, maka Abraham mampu membuktikan kecintaannya kepada Allah melebihi kecintaannya kepada putra-putranya. Balasannya, dia dipilih oleh Allah yang kemudian berjanji kepada Abraham dan keturunannya untuk menjadikan mereka penguasa dunia dan memberikannya "Tanah Perjanjian"; tempat yang akan menjadi pusat kekuasaan dari keturunannya kelak ${ }^{34}$.

Dalam konteks al Quran, perjuangan Abraham dilanjutkan oleh keturunannya, Yaqub anak Ishak. Yaqub mendapat julukan Israil yang merupakan ayahnya Yusuf. Sepeninggal Yusuf Allah mengutus nabi Musa untuk mengeluarkan mereka yang masih beragama tauhid dari Mesir ${ }^{35}$. Pada zaman sesudahnya, mereka memfitnah Maryiam melakukan zina, dengan terlahirnya Isa As. Sehingga mereka menentang dan menolak ketika nabi Isa mengatakan bahwa ia adalah utusan Allah Swt ${ }^{36}$.

Fase kedua adalah kaum Yahudi yang hidup pada era kenabian Muhammad Saw. Dalam kontek ini al Quran berbicara bagaimana karakteristik orang-orang Yahudi. Mereka menetap di Yastrib dan menjadi penguasa tanah Yastrib sehingga mereka disebut dengan Yahudi Israil Al Musta'ribah. Kaum Yahudi Madinah terbagi kedalam kedua kelompok, Yahudi besar yang terdiri dari bani Qainuqa, bani Nadzir, dan bani Quraidzoh. Mereka adalah keturunan bani Israil. Sementara kelompok kecil yakni suku auz dan khazraj. Mereka merupakan ketrurunan Arab Qahthaniyah ${ }^{37}$. Orang-orang yahudi yang tinggal di Madinah dan hidup berdampingan dengan dengan masyarakat Arab. Dengan merekalah Rasulallah mengadakan perjanjian untuk sama-sama menjaga Madinah dari serangan yang datang dari luar, menjaga kebebasan menjalnkan tradisi masing-masing, harta-harta mereka, tempat sembahan, hak dan kewajiban bersama, termasuk hak beragama yang selanjutanya dalam sejarah dikenal dengan Piagam Madinah. ${ }^{38}$

Menganalisis Yahudi adalam al Quran, Muhammad Izzat Darwah memberikan formulasi karakteristik yahudi berdasarkan ayat-ayat al Quran sebagai berikut: pertama,

wahyu atau pesan Ilahi dan dia berbicara atas nama Tuhan. Jerlad F. Dirks,Abrahamic Faiths: Titik Temu dan Titik Seteru antara Islam, Kristen, dan Yahudi, Jakarta: Serambi, 2006, hal. 44.

34. The Ilustrated World's Religion: A guide to Oue Wsidom Traditions, Huston Smith, UK, Labyrnith Publishing, 1994.

35. Surat Al Baqoroh ayat 51. Disini mulai nampak karakter-karakter pengingkaran orang yahudi. Begitu mereka selamat dari Firaun. Justru mereka menolak agama yang dibawa musa dengan misi yang sama yakni Tauhid.

36. Muhammad Izzat Darwazah, Al Yahud fi Al Quran, Kairo, Dar Ihya al Kutub Al Arabiyyah, hal 28-58. Asal ushul yahudi dan konteks bahasa yang digunaakan lihat lebih lanjut Muhammad Syaid Asmawi, al ushul al mishiriyah li al Yahud, Libanon, Bairut, al Intrisar al Arabi, 2004.

37. Muhammad Syaid Asmawi, al ushul al mishiriyah li al Yahud, Libanon, Bairut, al Intrisar al Arabi, 2004. Hal 135.

38. Akram dhiya Umari, Al Sirah Nabawiah as Sahihah; muhawalatun fi tatbiqi qawaidh al muhaditsin fi naqdi riwayat al sirah an nabawiyah, Riyadh: Maktabah Obikan, 2013, hal 315. 
sikap mereka terhadap dakwah kenabian Muhammad Saw.; kedua, sikap mereka yang bersifat argumentatif; ketiga, sikap mereka yang suka memrekayasa dan memfitnah; keempat, peristiwa intimidasi yang diciptakan oleh mereka sendiri; kelima, minoritas orang-orang yahudi yang moderat dan muslim yang adil serta siginifikansinya ${ }^{39}$.

Pertama, sikap mereka yang menentang dakwah Muhammad hal ini tertuang dalam surat al Baqoroh ayat 47-53, ayat 58-59, 61-63, 67-74, 75-80, 83-85, 87-93, 99-101. Pelajaran yang diambil dari ayat-ayat tersebut menurut Darwazah adalah; pertama, al Quran dalam mengungkapkan serangan atau kecaman terhadap tindakan kaum yahudi dengan menggunakan gaya ungkapan berbentuk kisah. Sehingga ayat-ayat tersebut dapat difahami dalam satu kesatuan dengan konteks cerita yang berbeda-beda; kedua, serangan al Quran terhadap kaum Yahudi kaitannya dengan ayat-ayat di atas berhubungan dengan kesatuan tabiat dan akhlak mereka dalam setiap generasi; ketiga, gambara yang jelas tentang sikap-sikap mereka yang suka menentang dapat ditemui kesamaan kendati konteks ayat tersebut berbeda-beda; keempat, al Quran menegaskan bahwa sikap mereka menentang dakwah kenabian Muhammad dimulai sejak periode awal di Madinah.

Kedua, sikap mereka yang argumentatif. Diantara argumentasi mereka adalah klaim bahwa hanya merekalah yang mendapat petunjuk tuhan ${ }^{40}$. Mereka mengklaim bahwa kaum Yahudi berada dalam petunjuk berkaitan dengan keyakinan mereka " Uzair adalah anak Allah". Al Quran menyanggah kliam mereka mengenai Ibrahim dan agamanya. Bahwa posisi Ibrahim sebagai bapak kaum Yahudi tidak dengan sendirinya mesti menjadikan mereka beragama dengan agama Ibrahim.

Dalam hal ini al Quran menegaskan Ibrahim bukanlah musyrik, bukan penganut agama Yahudi atau Nasrani, melainkan penganut agama yang hanif dan muslim ${ }^{41}$. Yang selanjutnya disebut Islam dalam agama yang dibawa oleh Muhammad Saw. Kaum Yahudi kendati mengetahui akan berita tersebut mereka menolak untuk menerima kenabian Muhammad Saw karena mereka bukan dari keturunan Ishak akan tetapi dari keturunan arab dari jalur Ismail.

Ketiga,sikap mereka yang suka memrekayasa dan memfitnah. Banyak terdapat beberapa ayat dalam al Quran yang melarang umat Islam percaya seutuhnya dengan orang

39. Dalam literaur Isalam kajian Yahudi berdasarkan qisash quraniyah Muhammad Izzat Darwah, Yahud fi Al Quran Kariem mewakili cendekiawan muslim yang mengupas secara kronologis dan historis. Anlisis darwah diperkuat dengan hadirnya karya beliau yang serupa yakni tarikh bani israil min asfarihim, kairo, maktabah nahdzah, 1958. Lebih lanjut lihat aksin wijaya, sejarah kenabian,bandung, Mizan, 201, hal 426.

40. Sayyid Muhmmad al Qimni, Nabi Ibrahim; Titik Temu-Titik Tengkar Agama-Agama,dalam terjemah Karman As'ad Irsyady, Yogyakarta; LKIS, 2004, hal 2-3.

${ }^{41}$. Surat Al Imron ayat 65-68. 
Yahudi karena mereka selalu melakukan pelanggaran dan menipu umat Islam. Dimana mereka menyebut istilah"rahina" kepada Muhammad untuk menyakitinya. Dalam konteks sejarah salah satu tipu daya mereka yang sangat ampuh menyebabkan kegelisahan umat Islam adalah peristiwa perubahan arah qiblat. Oleh karena itu al Quran memberikan peringatan kepada umat Islam untuk berhati-hati dari hasutan, perkataan dan tipu daya orang Yahudi ${ }^{42}$.

Keempat, peristiwa intimidasi yang diciptakan oleh mereka sendiri. Dalam konteks ini kaum Yahudi tidak sebatas menentang kenabian Muhammad, kebenaran al Quran sebagai wahyu Ilahi, bersikap sombong dan keras kepala. Intimidasi yang mereka lakukan mengkianati, mengingkari janji dengan Allah untuk menjalankan sepuluh washiyat yang telah diberikan kepada nabi Musa $\mathrm{As}^{43}$. Pada awal periode Madinah mereka telah memiliki perjanjian dengan kaum muslim namun berkali-kali mereka melanggar perjanjian tersebut.

Kelima, minoritas orang-orang Yahudi yang moderat dan muslim yang adil serta siginifikansinya. Al Quran juga menyinggung sebagian kaum Yahudi yang bersikap moderat yang menerima dakwah dan kenabian Muhammad Saw. Terkait hal ini al Quran sama sekali tidak menolak atau menentang kaum Yahudi sebagai agama. Karena pada hakikatnya semua pesan agama yang dibawa adalah seruan untuk beribadah kepada Allah, berakhlak yang baik, mengajak dengan bijaksana ${ }^{44}$. Sikap keras yang ditunjukan al Quran terhadap orang Yahudi tidak terlepas dari bagaimana sikap keras mereka menyikap dakwah Muhammad Saw dan umat Islam. Dalam hal ini Rasulullah sendiri diperintahlan untuk berdakwah dan berdialog dengan cara yang baik dengan mereka yang bersikap lunak dan moderat terhadap Nabi dan umat Islam ${ }^{45}$.

\section{b. Nasrani}

Dalam menjalankan misi ketuhanan, al-Qur'an sebagai wahyu yang diturunkan kepada nabi Muhammad pada dasarnya mempunyai istilah self definition (pendefinisian diri) atau self consciousness ${ }^{46}$. Yakni pemahaman yang dibentuk untuk membangun "identitas" yang tersemat dalam dirinya sendiri. Self definition bertujuan untuk membangun pandangan dunia terhadap al-Qur'an. Dalam hal ini pula al Quran sebagai kitab suci terakhir dalam agama semit yang menyempurnakan kitab-kitab sebelumnya

\footnotetext{
42 . Lihat tafsir surat Al Baqoroh ayat 104.

43. Muahmmad Abid Al Jabiri, Madkhal Ila Fham Al Quran Al Karim, Bairut, Makaz Dirasat Al Wahadah Al Arabiyah, 2007, hal 401-403.

44 . Muhammad Izzat Darwazah, Sirah Ar Rasul, Jilid 2, hal 207, 211, hal serupa dikemukakan dalam Sejarah Kenabian, Aksin Wijaya, hal 449.

45 . Lihat Tafsir Surat Al Ankabut ayat 46.

46. Jane Dammen Mcauliffe, Qur'anic Christian; An Analysis Of Classical And Modern Exegesis, New York: Cambridge University Press, 1991, hal. 1
} 
membicarakan hal yang sebagai pembawa misi ketuhanan. Sehingga kesamaan misi yang dibawa untuk umat manusia inilah al Quran mengisahkan eksistensi agama Abrahamic lainnya selain Yahudi yakni Nasrani.

Lafadz al-nasara merupakan salah satu term yang paling jelas disinggung dalam alQur'an. Lafadz tersebut ditemukan sebanyak tujuh kali dalam surah al-Baqārah, lima kali dalam surah al-Mā'idah, dan sekali dalam surah at-Taubah dan surah al-hajj. Pada dasarnya Kristen sering disebut dengan menggunakan term ahlu al-kitab (orang yang diberi kitab) yang terdapat lebih dari tiga puluh kali penyebutan dalam al-Qur'an. Selain itu, term lain yang juga senada adalah alladzina utu al-kitab, alladzina atainahum alkitab, alladzina utu nashiban min al-Kitab, alladzina yaqraunaa al-kitab min qablik ${ }^{47}$. Pembahasan tentang Nasrani ditemui dalam beberapa surat diantaranya surah al-Baqarah : 62; surah ali Imran: 55, 199; surah al-Maidah: 66, 82-83; al-Qasas: 52-55; dan al-Hadid: 27.

Dalam surat al Baqarah ayat 62 "Sesungguhnya orang-orang mukmin, orang-orang Yahudi, orangorang Nasrani dan orang-orang Shabiin, siapa saja diantara mereka yang benar-benar beriman kepada Allah, hari kemudian dan beramal saleh, mereka akan menerima pahala dari Tuhan mereka, tidak ada kekhawatiran kepada mereka, dan tidak (pula) mereka bersedih hati." Ayat di atas pada dasarnya menggambarkan eksistensi umat Kristen yang diakui oleh al-Qur'an sebagai "komunitas religius". Dan dalam ayat ini dipaparkan pula bahwa baik Islam, Kristen maupun Yahudi sama-sama mempunyai peluang untuk mendapatkan rahmat Tuhan. Dengan syarat, mereka beriman kepada Tuhan dan hari akhir serta beramal saleh.

Menurut Mcauliffe lafadz Nasrani yang terdapat dalam surat al Baqarah ayat 62, setidaknya mengandung tiga makna, pertama menolong, arti ini diambil dari linguistik lafadz Nasrani yang seakar dengan lafadz nasr yang berarti pertolongan; kedua Nashara identik dengan nama tempat, nasirah. Nama tempat tersebut identik dengan tempat dimana Yesus hidup, yakni Nazareth; ketiga Nashara hampir semakna dengan makna pertama yakni sebagai penolong. Arti tersebut serupa dengan makana yang terkandung dalam surat as Shafat ayat 14 "ansharallah" 48 .

Jelaslah bahwa kata 'nashaaraa' dalam bahasa Al Quran adalah 'anshaar'. Kata kerja 'anshaar' adalah 'nashara' yang berarti 'mendukung, membantu, menolong,

47 . Jane Dammen Mcauliffe, Qur'anic Christian; An Analysis Of Classical And Modern Exegesis, New York: Cambridge University Press, 1991, hal. 3

${ }^{48}$ Jane Dammen Mcauliffe, “Quranic Hermeneutics: The Views Of Al-Tabari And Ibn Kathir”, dalam Andrew Rippin (ed), Approaches To The History Of The Interpretation Of The Qur'an, (Oxford: Clarendon Press, 1988) hal. 46 
mendampingi. dan sebagainya. Jadi, 'anshaar' berarti 'para pendukung'. Konteks kata tersebut menunjukkan konteks religius dan makna khusus kata 'anshaar' ketika dugunakan untuk menyebut orang-orang Kristen. Istilah 'anshaar' ditemukan dalam konteks penyebutan orang-orang Kristen sebagai 'anshaar Isa dijalan Allah' yang pada dasarnya berarti ‘para pendukung Allah' yang mengikuti ajaran dibawa oleh Isa As.

Al Quran lebih banyak menyebutkan kaum Nasrani yang ada di Madiah dibanding di Makah ayat-ayat tentang Nasrani jauh lebih sedikit jika dibandingkan dengan ayat-ayat terkait Yahudi. Dalam al Quran fase Makiyyah secara umum kaum Nasrani disifati baik dikarenakan mereka lebih siap menerima dakwah kenabian Muhammad Saw. Sedangkan di dalam fase Madaniyah, terdapat banyak ayat yang berbicara tentang kaum Nasrani terkiat akidah serta perbedaan yang ada dalam teologi mereka, begitu pula banyak membicarakan tentang Isa, Maryam dan kaum Hawariyun ${ }^{49}$.

Menurut Darwazah alam konteks kebahasaan gaya bahasa yang digunakan al Quran terkait Nasrani diungkapkan bernada cinta dan pujian yang indah, sebagian menggunakan gaya ungkapan bernada mengingat dan mengecam, sebagian lagi menggunakan ungkapan gaya debat dan argumentassi, kisah, serangan, dan sebagian lagi menggunakan gaya ungkapan yang bernada keras dan perintah berperang ${ }^{50}$.

Masih menurut Darwazah tema pembahasan al Quran seputar kaum Nasrani, bisa dibagi menjadi empat kategori, sebagai berikut:

Pertama, gambaran al Quran tentang kondisi kaum Nasrani. Dalam surat al Baqarah ayat 253, selanjutnya surat al Maidah ayat 15-16 berbicara ahli kitab secara umum, baik Yahudi dan Nasrani. Kedua ayat tersebut secara lebih spesifik membicarakn tentang Isa al Masih yang membawa agama Nasrani. Al Quran dalam sura al Maidah ayat 14, membicarakan penyimpangan yang dilakukan kaum Nasani yang hidup pada zaman Rasulullah terhadap janji wasiat Allah sehingga terjadi perselisihan dan permusuhan diantara mereka. Oleh karena itu, al Quran memberi peringatan kepada mereka untuk berjalan sesuai kitab sucinya, yakni kitab Injil $^{51}$.

Di sisi lain, al Quran dalam surat al Hadid ayat 27, memberi pujian kepada kaum Nasrani yang mengikuti nabi Isa dengan hati yang tulus, termasuk para rahib yang tulus mencari ridah Allah. Al Quran surat al Maidah ayat 111 pula meberikan pujian terhadap kaum Hawariyyin yang menjadi penolong Isa. Sebaliknya, dalam surat as Shaf ayat 14 al

\footnotetext{
49. Aksin Wijaya, Sejarah Kenabian, Bandung, Mizan, 2016, Hal 451-452.

50. Muhammad Izzat Darwazah, Sirah al Rasul, Jilid 2, hal 212-213. Hal serupa diungkapkan dalam Sejarah Kenabian, Aksin Wijaya, hal 452.

51 . Lihat tafsir surat al Maidah ayat 46-47.
} 
Quran mengecam kelompok yang tidak mengindahkan ajaran kitab suci dan para rahib. Ayat-ayat tersebut memberikan pelajaran kepada umat Islam untuk membangun hubungan mawadah dan rahmat dengan kaum Nasrani yang hidup di era kenabian Muhammad ${ }^{52}$.

Di samping itu al Quran juga mengkritik keras kaum Nasrani yang meyakini keilahian Isa al Masih dengen menyebut mereka sebagai orang kafir. Kaum Nasrani yang mengatakan keilahian Isa al Masih itu adalah kufur, dan karena itu diharapkan kembali ke jalan yang benar, yakni ajaran kitab suci yang dibawa Muhammad $\mathrm{Saw}^{53}$.

Kedua, sikap mereka terhadap dakwah kenabian. Al Quran dalam surat al Maidah ayat 19 mempertegas bahwa risalah kenabian Muhammad mencakup kedua agama ahli kitab. Secara lebih khusus mengajak kaum Nasrani untuk menjauhi kebathilan yang tidak sejalan dengan kebesaran Allah dan sifat-sifatNya yang sempurna, dan menegaskan bahwa Isa dan malaikat tidak mungkin mengingkari untuk beribadah kepada Allah ${ }^{54}$.

Dalam surat al Baqarah ayat 120-121 dijelaskan sikap penentangan yang keras dari sebagaian kaum Nasrani terhadap dakwah kenabian Muhammad. Penyebab sikap penentangan mereka yang keras itu, menurut Darwazah dikarenakan mereka terlalu fanatis terhadap rahib-rahib mereka, terutama sikap menuhankan Isa al Masih akibatnya mereka menentang dakwah Muhammad ${ }^{55}$.

Ketiga, sikap argumentatif kaum Nasrani . Surat al Imran ayat 65-68 menurut para mufasir dengan berbagai riwayatnya berhubungan dengan diskusi Muhammad bersama kaum Nasrani terkait tentang nabi Isa dan persoalan teologis yang dipermasalahkan. Terkait hal ini, dapat ditemui dalam al Quran mengisahkan perkataan yang saling mengklaim antara kedua ahli kitab, Yahudi dan Nasrani tentang siapakah yang paling berhak menyandang kebenaran dan petunjuk. Al Quran menyinggung sikap kedua ahli kitab itu terhadap nabi Muhammad yang diminta oleh Allah untuk mempertegas kebenaran bahwa yang memberi petunjuk bukan Yahudi dan Nasrani. Hanya Allah yang berhak memberi petunjuk melalu Islam yang dibawa oleh Muhammad.

Keempat, konflik antara Nabi dan umat Islam dengan kaum Nasrani. Menurut Darwazah Al Quran memberikan indikasi terjadinya konflik antara nabi Muhammad dan

\footnotetext{
52 . Aksin Wijaya, Sejarah Kenabian, Hal 453-454.

53. Muhammad Izzat Darwazah, Sirah al Rasul, Jilid 2, hal 220-222.

54 . Tafsir Surat an Nisa ayat 171-173, lebih lanjut lihat Muhammad Izzat Darwazah, Muhammad Izzat Darwazah, Sirah al Rasul, Jilid 2, hal 223-224.

55. Muhammad Izzat Darwazah, Sirah al Rasul, Jilid 2, hal 227
} 
umat Islam dengan kaum Nasrani sebagaimana yang terdapat dalam surat at Taubah ayat $38-42^{56}$.

\section{c. Shabiin}

Al Quran menceritakan tentang Shabiin dalam konteks bahwa berita tentang kedatangan Nabi baru yang berasal dari masyarakat keturunan Arab, diharapkan kedatangannya oleh dua golongan yakni Shabiin dan Hunafa ${ }^{57}$. Al Quran menyebut agama Shabiin dalam tiga ayat, yakni surat Al Baqarah ayat 62, Al Haj ayat ayat 17 dan surat al Maidah ayat 69. Dalam surat al Baqarah dan al Maidah Shabiin disebut besamaan dengan orang-orang Mukmin, Yahudi dan Nasrani. sedangkan dalam Surat al Haj Shabiin disebut berbarengan dengan orang-orang Musyrik dan Majusi.

Para Mufasir berbeda pendapat terkait hakikat Shabiin. Sebagian berpendapat bahwa Shabiin adalah bagian dari agama Majusi, penyembah malaikat, penyembah binatang, dan penyembah matahari. Sedangkan pendapat lain shabiin mentalfiq ${ }^{58}$ ajaran Yahudi dan Nasrani. Shabi'in ialah orang-orang yang mengikuti syari'at nabi-nabi zaman dahulu atau orangorang yang menyembah bintang atau dewa-dewa. Menurut sebagain mufasir asal arti kata maknanya, ialah orang yang keluar dari agamanya yang asal, dan masuk ke dalam agama lain, sama juga dengan arti asalnya ialah murtad. Sebab itu ketika Nabi Muhammad mencela-cela agama nenek-moyangnya yang menyembah berhala, lalu menegakkan paham Tauhid, oleh orang Quraisy, Nabi Muhammad s.a.w itu dituduh telah shabi' dari agama nenek-moyangnya karena keluar dari syariat nabi-nabi sebelumya ${ }^{59}$.

Menurut riwayat ahli-ahli tafsir, golongan Shabi'in itu memanglah satu golongan dari orang-orang yang pada mulanya memeluk agama Nasrani, lalu mendirikan agama sendiri. Menurut penyelidikan, mereka masih berpegang teguh pada cinta kasih ajaran alMasih, tetapi disamping merekapun mulai menyembah Malaikat. Kata setengah orang pula, mereka percaya akan pengaruh bintang bintang. Ini menunjukan pula bahwa agama menyembah bintang bintang pusaka Yunani mempengaruhi pula perkembangan Shabi'in.

Terdapat banyak pengertian yang disampaikan oleh para mufassir mengenai kata shabi' in ini. Salah satunya pendapat mujahid yang dikutip oleh Ibnu Katsir, shabi'in adalah segolongan Nasrani, Yahudi dan majusi yang tidak beragama. Menurut Qatadah Shabi'in

${ }_{57}^{56}$. Menurut Izzat Darwazah yang dikutip dari Aksin Wijaya dalam Sejarah Kenabian, Hal 460-462.

57. Muhammad Izzat Darwazah, Ashrar An Nabi wa Baiatuhu Qabla al Bi'tsah, Bairut, 1964, hal 695. Hal serupa diutarakan oleh Muhammad Abdullah Darraz, dalam Madkha Ila Al Quran al Kariem,Kuwait, Dar Al Qalam,2003, hal 142. Aksin Wijaya, Sejarah Kenabian, hal 285.

58 . Mentalqif disini mereka mereka menggabungkan antara syariat yang dibawa oleh agama Yahudi dan syariat yang dibawa oleh agama Nasrani.

59 . Aksin Wijaya, Sejarah Kenabian, hal 285-286. 
adalah orang yang menyembah malaikat, shalatnya tidak menghadap kiblat dan mereka membaca Zabur. Ibn Wahab berkata "Ibn Abi Ziyad menceritakan kepada saya dari ayahnya dia berkata: Shabi'in adalah kaum oyang tinggal dekat Irak, yaitu Bakausi. Atau mereka adalah orang-orang yang beriman kepada seluruh Nabi, puasa 30 hari pada setiap tahun dan shalat menghadap Yaman lima kali sehari ${ }^{60}$.

Menurut Sayyid Qutbh, pada umumnya Shabiin adalah golongan penyembah berhala sebelum diutusnya Rasulullah Saw. Dan orang-orang yang menyembah Allah saja tanpa 5 mengikuti agama tertentu. Orang seperti ini banyak terdapat dikalangan bangsa Arab. Senada dengan pendapat Qutbh, Rudi Paret, sebagaimana dikutip oleh Adnan Amal, nama ini biasanya dikaitkan dengan pengikut dua sekte keagamaan yang terpisah yakni pertama, Orang mandean atau Subba yang mempraktekkan ritus baptisdi Mesopotamia; kedua, Orang Sabean di Harran yang merupakan sekte Paggan penyembah bintang. Tidak jelas sekte manakah yang disebutkan oleh Al-Qur'an dengan istilah shabiun. Para ahli berbeda pendapat tentang hal ini. Pada masa penyebarluasan Islam yang belakangan, baik orang-orang shabiin maupun Majusi diperlakukan sebagai ahl al-kitab ${ }^{61}$.

\section{d. Islam}

Islam adalah agama yang ajarannya diwahyukan Tuhan kepada masyarakat manusia melalui Muhammad Saw. Islam pada hakikatnya membawa ajaran-ajaran yang bukan hanya satu segi, tetapi mencakup segala segi dalam kehidupan manusia.

Kata "Islam" tidak diasosiasikan pada pribadi seseorang, nama ras, suku, ataupun wilayah. Dan Islam mengandung pengertian dan prinsip-prinsip yang dapat didefinisikan secara terpisah dan bila dipahami secara menyeluruh merupakan pengertian yang utuh. Sebagaimana yang terdapat dalam surat Al Imran:19, Al Imran:67, Al Imran:83, Al hajj: 18, dan Asy-syura: 13.

Secara etimologi kata Islam berasal dari bahasa Arab, kata kerja "aslama", secara harfiah ia berarti "ketundukan" atau "penyerahan diri sepenuhnya kepada kehendak yang lain". Kalimat "muslim"berarti "orang yang menyerahkan diri". Ketika disandingkan dengan kata "iman", maka kata "islam" oleh sebagian orang diartikan dengan "langkah yang paling awal dari keyakinan, yakni kepercayaan dangkal yang belum merasuk kedalam hati yang dalam"62. Turunan katanya salima yang berarti selamat. Kemudian dibentuk

60 . IbnuKatsir,Tafsir al-Qur'an al-Adzim, Jakarta: GemaInsani Press, 1999, hlm. 126-127.

61. Taufik Adnan Amal, RekonstruksiSejarah Al-Qur'an, Yogyakarta: FkBA, 2001, hlm. 22. Terkiat hal ini dibahas oleh Ade Jamarudin dalam Artieklnya Kajian Pluralitas Agama dalam Kata Kunci Ahlul Kitab. Journal Ushuludin Vol XIX No 1, Januari 2013.

62. Toshiko Izuttsu, Etika Beragama dalam Qur'an, Jakarta: Pustaka Firdaus, 1995, 
menjadi aslama yang berarti taat dan berserah diri. Sehingga terbentuk kata Islam (aslamayuslimu-islaman) yang berarti damai, aman, dan selamat. Orang yang masuk Islam dinamakan Muslim.

Menuurt Waryono dengan mengutip pendapat Thabathabai, mengatakan bahwa Islam, taslim, dan istislam mempunyai arti yang sama, yakni tunduk patuh dan menerima hukum-hukum Allah. Islam itu mempunyai hierarki, yaitu; Pertama, menerima dan mematuhi (secara lahiriah) perintah dan larangan Allah SWT dengan

mengucapkan kalimah syahadat, tidak menjadi soal apakah ia mengucapkan dengan sepenuhhati atau tidak. Islam semacam ini sebagaimana yang disabdakan oleh Allah dalam al Hujurat ayat 14. Kedua, kepasrahan dan ketundukan hati untuk menerima keyakinan yang benarsecara terperinci dengan diikuti oleh amal saleh, sungguhpun kadang-kadang ia berbuat salah sebagaimana firman Allah dalam al Baqarah ayat 208, al Hujurat ayat 15, al Shaff ayat 11. Ketiga, sebagaimana Islam pada level kedua dengan disempurnakan dengan akhlak yang sesuai dengan tuntunan iman, yang membuat semua sifat dan kecenderungan kepada dunia tunduk. Pada level ini dalam beribadah seolah-olah ia melihat Allah yang selanjutnya dikenal dengan term Ihsan. Keempat, adalah tingakatan di atas Ihsan bahwa ia benar-benar melakukan pengabdian dan tunduk sepenuhnya kepada keinginan dan kehendak Tuhan, menerima apa yang dicintai dan diridaai-Nya ${ }^{63}$.

Hal senda diutaran Ibnu Kasir dalam surat al Imran ayat 83 pada tafsir ayat

"Dan barang siapa menganut agama selain sikap pasrah (al-Islam) itu, ia tidak akan diterima, dan diakhirat termasuk orang-orang yang merugi”. Menurut Ibnu Katrsi mereka yang pasrah (muslimun) itu mengatakan yang dimaksud ialah "mereka dari kalangan umat ini yang percaya pada semua Nabi yang diutus, pada semua Kitab Suci yang diturunkan, mereka tidak mengingkarinya sedikitpun, melainkan menerima kebenaran segala sesuatu yang diturunkan dari sisi Tuhan dan dengan semua Nabi yang dibangkitkan oleh Tuhan" ${ }^{64}$. Sedangkan al Zamakhsari dalam al Khasaf memberi makna pada perkataan Muslimun sebagai "mereka yang bertawhid dan mengikhlaskan diri padaNya," dan mengartikan al-Islam sebagai sikap memaha-esakan (ber-tawhid) dan sikap pasrah diri kepada Tuhan" ${ }^{65}$.

307.

63. Waryono Abdul Ghafur. Millah Ibrahim dalam al-Mizan fi Tafsir al-Qur'an Karya Muhammad Husein ath-Thabathabai, Yogyakarta: Bidang Akademik UIN Sunan Kalijaga, 2008, hal 197. Hal senada disampaikan oleh Imam Ibnu Hajar dalam Sejarah Agama dalam Al quran.

64. Tafsir Ibn Katsir ,Beirut: Dar al-Fikr, 1984 M jilid 1, hal. 380.

65. Tafsir al Khasaf, Teheran: Intisharat-e Aftab, jilid 1, hal. 442 
Berbeda halnya dengan pendapat Muhammed Arkoun yang tidak menggunakan term Islam dengan istilah "kepasrahan" yang kadang dipakai untuk memperjelas arti "penyerahan". Arkoun berargumen bahwa manusia muslim tidak disuruh pasrah di hadapan Tuhan. Yang ada adalah ungkapan syukur akan nikmat dari pengangkatan derajat manusia muslim oleh Allah, sehingga menimbulkan hubungan ketaatan yang penuh rasa cinta dan syukur antara al Khaliq dan makhluq. Sehingga Arkoun mendefinisikan Islam yang cenderung memberi arti dengan "memberikan (mempercayakan) keseluruhan jiwa (raga) seseorang kepada Tuhan (Allah) ${ }^{66}$.

Terkait penamaan Islam Sadullah mengutip Joseph Schact mengemukakan tentang Islam bahwa Islam tidak dinisbatakan kepada pembawanya Muhammad. Islam tidak dikatakan dengan Muhammadanism sebagaimana istilah Kristen yang dijadikan nama bagi pengikut Yesus Kristus ${ }^{67}$. Islam dalam arti intuisi resmi dimulai saat diutusnya Muhmmad pada usia 40 tahun pada abad ke 7 M, saat menyendiri di Gua Hira. Sebagai tradisi ajaran Hanif yang menjadi keyakinan leluhurnya. Dan salah satu bukti kenabian bahwa Muhammad tidak mengikuti kepercayaan orang Quraisy yang berkembang saat itu ${ }^{68}$.

Karen Amstrong mengemukakan Islam sebagai ajaran yang dibawa Muhammad sebagai kelanjutan dari ajaran agama monoteisme sebelumnya yakni Yahudi dan Nasrani yakni kepercayaan kepada Allah yang menciptakan dunia dan akan memintakan tanggung jawab dalam peradilan manusia di hari Akhir ${ }^{69}$. Hal senada diungkapkan oleh Philip Hitti, Islam dengan al Qurannya merupakan satu dari tiga agama monoteisme yang berkembang di wilayah semith. Islam dianggap sebagai agama yang paling mirip dengan Yahudi dalam Perjanjian Lamanya, dari pada dengan kristen dalam Perjanjian Barunya. Sehingga ini lah yang kemudian diasumsikan bahwa Islam bukan sebagai agama baru ${ }^{70}$.

Dari beberapa defenisi diatas membuat defenisi terkait Islam yang sangat komprehensif memang sulit. Sehingga banyak defenisi yang sangat beragam. Namun dari beberapa yang diuraikan terkait Islam yang dilihat sebagai agama samaei terakhir yang bersifat universal. Disamping itu defenisi Islam yang lain sebagai agama yang bersandarkan wahyu ilahi guna mencari jalan kebahagian dunia dan akherat dengan menunjukan kepatuhan dan kepasrahan dan ketaatan terhadap Allah. Sehingga pemaknaan

${ }^{66}$. Mohammed Arkoun, Rethingking Islam, Yogyakarta: LPMI dan Pustaka Pelajar,1996, hal 17.

67 . Joseph Schact, The Origins of Muhammad Jurispurdance, Oxford, 1959. Hal serupa dikemukakan dalam bukunya yang lain dengan judul An Intoduction to Islamic Law dalam Menyoal Status Agama Pra Islam, hal 184.

68. Abdul Karim, Hegemony Quraisy, hal 184.

69 . Karen Amstrong, Islam: A Short History terj, Surabaya, Ikon Teralitera, 2004, hal 4.

70 . Philip K. Hitti, History of The Arabs terj, Jakarta, Serambi, 2008. Hal 160. 
Islam ini lebih universal sebagaimana yang terdapat dalam surat al Imran ayat 19 dan 85 . Keuniversalan ini diartikan bahwa Islam adalah sikap pasrah kepada Tuhan Yang Maha Esa, artinya semua ajaran yang datang sebelum Islam menyampaikan misi yang sama. Agama yang datang sebelumnya tidak dikatakan dengan Islam sejalan dengan lingkungan, bahsa, dan pola pikir.

\section{Perspektive al-Qur'an Terhadap Agama-Agama Pra-Islam}

Perbedaan termasuk di dalamnya agama-agama, merupakan sunatullah sebagaimana yang terdapat dalam al-Qur'an surat al Maidah ayat 48. "Untuk tiap-tiap umat di antara kamu Kami berikan aturan dan jalan. Seandainya Allah menghendaki, niscaya Dia menjadikan kamu satu umat, tetapi Allah hendak menguji kamu menyangkut anugerah-Nya kepadamu, maka berlomba-lomba berbuat kebajikan”.Pemaknaan serupa terdapat dalam surat Hud ayat 18 "Jikalau Tuhanmu menghendaki, tentu Dia menjadikan manusia umat yang satu, tetapi mereka senantiasa berselisih pendapat”.

Dari ayat ini dapat dipahami bahwa kalau Tuhan mau, dengan sangat mudah akan menciptakan manusia dalam satu group, monolitik, dan satu agama, tetapi Allah tidak menghendaki hal-hal tersebut. Tuhan malah menunjukkan kepada realita, bahwa pada hakikatnya manusia itu berbeda-beda dan atas dasar inilah orang berbicara tentu keberagaman agama selanjutnya dipertegas dalam surat al Baqarah ayat 213.

Dari ayat-ayat tersebut setidaknya dapat diambil 3 fakta terkait dengan agamaagama pra-Islam, yaitu; Pertama, kesatuan umat dibawah satu Tuhan;Kedua, kekhususan agama-agama yang dibawa oleh para nabi; dan Ketiga, peranan wahyu (kitab suci) dalam mendamaikan perbedaan diantara berbagai umat beragama. Ketiganya adalah konsepsi fundamental Al-Qur'an tentang keberagaman agama ${ }^{71}$. Disatu sisi, konsepsi itu tidak mengingkari kekhususan berbagai agama, disisi lain konsepsi itu juga menekankan kebutuhan untuk mengakui titik temu atau kesatuan manusia dan kebutuhan untuk menumbuhkan pemahaman yang lebih baik antar umat beragama. Kemajemukan sangat dihargai dalam ajaran Islam, karena Islam sebagai Al-din merupakan agama Allah yang sesuai dengan fitrah kemanusiaan. Salah satu fitrah itu adalah kemajemukan yang hakikatnya bersumber dari ajaran agama.

Menurut Nurcholish, agama Islam memandang agama lain adalah: Pertama, Islam mengajarkan bahwa agama Tuhan adalah universal, karena Tuhan telah mengutus Rasul-

71. Syed Mahmudunnasir, Islam: Konsepsi dan Sejarahnya, Bandung: Remaja Rosdakarya, 1981, hlm. 3 
Nya kepada setiap umat manusia. Kedua, Islam mengajarkan pandangan tentang kesatuan nubuwwah (kenabian) dan umat yang percaya kepada Tuhan. Ketiga, agama yang dibawa Nabi Muhammad adalah kelanjutan langsung agama-agama sebelumnya, khususnya yang secara "genealogis" paling dekat ialah agama-agama Semitik-Abrahamik. Keempat, umat Islam diperintahkan untuk menjaga hubungan yang baik dengan orang-orang beragama lain, khususnya para penganut kitab suci (Ahl al-Kitab). Semua prinsip itu mengarah pada ajaran "tidak boleh ada paksaan dalam agama"72.

Dari segi teologis, yang didasarkan pada teologi inklusif, Islam memberikan landasan agamawi bagi para pemeluknya untuk menerima keberadaan agama-agama lain dan untuk mengadakan hubungan baik dengan agama-agama lain. Sikap umat Islam terhadap agama lain dan pola hubungan mereka dengan umat agama-agama lain dijelaskan oleh Kitab Suci Al-quran dan sesuai dengan konteks zamannya diterjemahkan oleh Nabi Muhammad dalam kehidupan bermasyarakat sebagaimana terabadikan dalam sunnah nabawi atau tradisi kenabian ${ }^{73}$. sebagaimana firman Allah dalam Surat an Nisa ayat 131, bahwa Semua kitab suci (Injil, Zabur, Taurat dan Al-Quran) membawa pesan Tuhan, diantaranya adalah pesan menjadikan manusia-manusia yang bertaqwa. Defenisi taqwa bukan sekedar tafsiran klasik, seperti sikap patuh kehadirat Tuhan.

Terkait konteks di atas Nurkholis Majid berpendapat bahwa pesan Tuhan itu bersifat universal dan merupakan kesatuan esensial semua agama samawi, yang mewarisi Abrahamic Religion, yakni Yahudi (Nabi Musa), Kristen (Nabi Isa), dan Islam (Nabi Muhammad). Lewat firman-Nya Tuhan menekankan agar kita berpegang teguh kepada agama Itu, karena hakikat dasar agama-agama itu (sebagai pesan Tuhan) adalah satu dan sama . Agama Tuhan, pada esensinya sama, baik yang diberikan kepada Nabi Nuh, Musa, Isa atau kepada Nabi Muhammad ${ }^{74}$.

Al Quran mensinyalir pesan universal terhadap agama-agama pra Islam hal ini dapat dilihat dalam beberapa surat, al Baqarah:130-132, al An'am:161-163, al Zumar :54. Berdasarkan ayat-ayat tersebut bahwa al Quran menegaskan agama para Nabi dan Rasul sebelum Muhammad adalah agama Islam. Yakni, agama yang mengajarkan sikap tunduk dan patuh, pasrah dan berserah diri secara tulus kepada Tuhan dengan segala qudrat dan iradat-Nya.

\footnotetext{
72 . Norcholis Madjid, Islam Kemodernan dan Keindonesiaan, Jakarta: Mizan, 1987, hlm. 70

73 . Eka Darmaputera, Strugglin in Hope, Jakarta: BPK-GM, 2004, hlm. 507

${ }^{74}$.Nurcholis Madjid, Islam Doktrin dan Peradaban; Sebuah Tealaah Kritis Tentang Masalah Keimanan Kemanusiaan dan Kemodernan, Jakarta: Paramadina, 1992, hlm. 226.
} 
Maka sebagai misal, mengenai Nabi Ibrahim ditegaskan bahwa dia bukanlah seorang penganut agama komunal seperti Yahudi atau Nasrani, melainkan dia adalah seorang yang tulus mencari dan mengikuti kebenaran (hanif) dan yang pasrah kepada Tuhan (muslim) ${ }^{75}$. Demikian pula agama seluruh Nabi keturunan Ibrahim, khususnya anak-cucu Ya'qub atau Bani Israil, sebagaimana dilukiskan dalam penuturan al Quran surat al Baqarah :133,Yunus:10,Al Imran :52.

\section{E. Penutup}

Agama, sejak dari nabi Adam As hingga nabi Muhammad Saw hanya satu disebut Islam, sedangkan ajaran-ajarannya bersifat dinamis. Keuniversalan agama-agama yang ada dalam al Quran membawa misi yang satu yaitu sebagai agama Tauhid. Implikasinya bahwa agama yang dianut jutaan manusia hadir untuk mengangkat derajat manusia dengan ketinggian moral berdasarkan pemakanaan ajaran Tuhan dengan ber-islam. Agama yang dibawa Muhammad Saw yang di dalamnya terdapat syariat, merupakan kompilasi dari syariat-syariat sebelumnya artinya Islam yang dibawa oleh Muhammad Saw tidak berati menganulir agama-agama terdahulu. Al Quran dalam menyebutkan agama-agama praIslam dengan sangat tegas khususnya terhadap kaum Yahudi ,konteks yang digunakan adalah terkait bagaimana psiko-sosio penganutnya dalam kehidupan Rasulullah Saw. Dalam konteks yang umum umat Islam diperintahkan untuk menjaga hubungan yang baik dengan orang-orang beragama lain, khususnya para penganut kitab suci.

\section{F. Daftar Pustaka}

Abdul Ghafur, Millah Ibrahim dalam al-Mizan fi Tafsir al-Qur'an Karya Muhammad Husein ath-Thabathaba'i, Yogyakarta:Bidang Akademik UIN Sunan Kalijaga, 2008. Abdurrazak Zabadi, Tajul Arus min Jawahir Qomus, Kuwait, th.

Abu al-A'la al-Mawdudi, Dasar-dasar Islam, penerj. Achsin Mohammad, Bandung: Pustaka, 1997.

Aksin Wijaya, Sejarah Kenabian; Perspektif Tafsir-Nuzuli Darwah, Kairo: Dar Ihya al Kutub Al Arabiyah,

Akram dhiya Umari, Al Sirah Nabawiah as Sahihah; muhawalatun fi tatbiqi qawaidh al muhaditsin fi naqdi riwayat al sirah an nabawiyah, Riyadh: Maktabah Obikan, 2013.

At Thabari, Jamiul Bayan Fi Tafsir Al Quran diakses melalui maktabah tafsir digital.

${ }^{75}$ Lihat surat al Imran ayat 67 
Al Qurtubi, Jami li Ahkam Al Quran, diakses lewat maktabah tafsir digital

Al Mizan fi Tafsir al Qur-an , Al A'lami, Beirut.

Ar Razi, Mafatihul Ghaib diakses melalui maktabah tafsir digital.

Cyrill Glasse, Ensiklopedi Islam (Ringkas), Jakarta: Raja Grafindo, 1999.

Eka Darmaputera, Strugglin in Hope, Jakarta: BPK-GM, 2004.

Huston Smith, The Ilustrated World's Religion: A guide to Oue Wsidom Traditions,UK:

Labyrnith Publishing, 1994.

Ibrahim Anis , Al-Mu'jam al-Waisth, Kairo, tth.

Ibn Manzhur, Lisan al-Arab, Cairo: Dar al-Ma'arif,tth.

Ibnu Katsir,Tafsir al-Qur'an al-Adzim, Jakarta: GemaInsani Press, 199.9.

Jerald F. Dirks,Ibrahim Sang Sahabat Tuhan, penerj. Satrio Wahono, Jakarta: Serambi, 2006.

Jerlad F. Dirks,Abrahamic Faiths: Titik Temu dan Titik Seteru antara Islam, Kristen, dan Yahudi, Jakarta: Serambi, 2006

Jane Dammen Mcauliffe, Qur'anic Christian; An Analysis Of Classical And Modern Exegesis, New York: Cambridge University Press, 1991

Jane Dammen Mcauliffe, Approaches To The History Of The Interpretation Of The Qur'an,Oxford: Clarendon Press, 1988.

Joseph Schact, The Origins of Muhammad Jurispurdance, Oxford, 1959

Karen Amstrong, Islam: A Short History terj, Surabaya, Ikon Teralitera, 2004.

Mohammed Arkoun, Rethingking Islam, Yogyakarta: LPMI dan Pustaka Pelajar,1996.

Muhammad Fu'ad 'Abdu al-baqi, Al-Mu'jam al-Mufahras Li Alfazh Alquran Al-Karim, Bairut: Dar al-Fikr, 1981.

Munawar Khalil, Defenisi dan Sendi Agama, Bulan Bintang, 1970.

M. Fuad Abdul Baqi, al-Mu'jam al-Mufahras lialfazh al-Qur'an al-Karim, Beirut: Mu'assah al-Jamal, Lebanon.

Muhammad Ali Subaih, Al Muwafaqat fi Ushul al Ahkam, Mesir, tth.

Muhammad Ali Ash-Shabuni, Kenabian dan Riwayat Para Nabi. Jakarta: PT. Lentera Basritama,2001

Muhammad Izzat Darwazah, Al Yahud fi Al Quran , Kairo: Dar Ihya al Kutub Al Arabiyyah.

Muhammad Izzat Darwazah, Sirah Ar Rasul, Beirut: Al Maktabah al Asyiriyah.tth.

Muhammad Izzat Darwazah, Tarikh Bani Israil Min Asfarihim,Kairo:Maktabah Nahdlah. 
Muhammad Izzat Darwazah, Ashrar An Nabi wa Baiatuhu Qabla al Bi'tsah, Bairut, 1964, hal 695

Muhammad Abdullah Darraz, Madkha Ila Al Quran al Kariem,Kuwait: Dar Al Qalam,2003.

Muhammad Syaid Asmawi, al ushul al mishiriyah li al Yahud, Libanon, Bairut: al Intrisar al Arabi, 2004.

Muahmmad Abid Al Jabiri, Madkhal Ila Fham Al Quran Al Karim, Bairut:Makaz Dirasat Al Wahadah Al Arabiyah, 2007.

M. Yudie R. Haryono, Bahasa Politik Alquran: Mencurigai Makna Tersembunyi di Balik Teks, Bekasi: Gugus Press, 2002.

Nurcholis Madjid, Islam dan Doktrin Peradaban, Jakarta, Paramadina.

Nurcholis Madjid, Islam Kemodernan dan Keindonesiaan, Jakarta: Mizan, 1987.

Nurcholis Madjid, Islam Doktrin dan Peradaban; Sebuah Tealaah Kritis Tentang Masalah Keimanan Kemanusiaan dan Kemodernan, Jakarta: Paramadina, 1992.

Philip K. Hitti, History of The Arabs terj, Jakarta, Serambi, 2008.

Sadullah Afandy, Menyoal Status Agama Pra Islam, Bandung: mizan, 2015.

Sayyid Muhmmad al Qimni, Nabi Ibrahim; Titik Temu-Titik Tengkar AgamaAgama,terjemah Karman As'ad Irsyady, Yogyakarta; LKIS, 2004.

Syed Mahmudunnasir, Islam: Konsepsi dan Sejarahnya, Bandung: Remaja Rosdakarya, 1981.

Taufik Adnan Amal, RekonstruksiSejarah Al-Qur'an, Yogyakarta: FkBA, 2001.

Toshiko Izuttsu, Etika Beragama dalam Qur'an, Jakarta: Pustaka Firdaus, 1995.

Waryono Abdul Ghafur. Millah Ibrahim dalam al-Mizan fi Tafsir al-Qur'an Karya Muhammad Husein ath-Thabathabai,Yogyakarta: Bidang Akademik UIN Sunan Kalijaga, 2008.

Zamaksyari, Tafsir al Khasaf, Teheran: Intisharat-e Aftab 